\title{
CHEMICAL EVOLUTION OF LEAKED HIGH-LEVEL LIQUID WASTES IN HANFORD SOILS
}

\author{
M. NYMAN, J. L. KRUMHANSL, P. ZHANG, H. ANDERSON, T. M. NENOFF
}

Sandia National Laboratories, P.O. Box 5800 MS-0710, Albuquerque, New Mexico, $87185-0710$

\section{ABSTRACT}

A number of Hanford tanks have leaked high level radioactive wastes (HLW) into the surrounding unconsolidated sediments. The disequilibrium between atmospheric $\mathrm{CO}_{2}$ or silica-rich soils and the highly caustic $(\mathrm{pH}>13)$ fluids is a driving force for numerous reactions. Hazardous dissolved components such as ${ }^{133} \mathrm{Cs},{ }^{79} \mathrm{Se},{ }^{99} \mathrm{Tc}$ may be adsorbed or sequestered by alteration phases, or released in the vadose zone for further transport by surface water. Additionally, it is likely that precipitation and alteration reactions will change the soil permeability and consequently the fluid flow path in the sediments. In order to ascertain the location and mobility/immobility of the radionuclides from leaked solutions within the vadose zone, we are currently studying the chemical reactions between: 1) tank simulant solutions and Hanford soil fill minerals; and 2) tank simulant solutions and $\mathrm{CO}_{2}$.

We are investigating soil-solution reactions at: 1) elevated temperatures $(60-200$ $\left.{ }^{\circ} \mathrm{C}\right)$ to simulate reactions which occur immediately adjacent a radiogenically heated tank; and 2) ambient temperature $\left(25^{\circ} \mathrm{C}\right)$ to simulate reactions which take place further from the tanks. Our studies show that reactions at elevated temperature result in dissolution of silicate minerals and precipitation of zeolitic phases. At $25^{\circ} \mathrm{C}$, silicate dissolution is not significant except where smectite clays are involved. However, at this temperature $\mathrm{CO}_{2}$ uptake by the solution results in precipitation of $\mathrm{Al}(\mathrm{OH})_{3}$ (bayerite). In these studies, radionuclide analogues ( $\mathrm{Cs}, \mathrm{Se}$ and $\mathrm{Re}-$ for $\mathrm{Tc}$ ) were partially removed from the test solutions both during high-temperature fluid-soil interactions and during room temperature bayerite precipitation. Altered soils would permanently retain a fraction of the Cs but essentially all of the Se and Re would be released once the plume was past and normal groundwater came in contact with the contaminated soil. Bayerite, however, will retain significant amounts of all three radionuclides.

\section{INTRODUCTION}

There are approximately 11 million cubic meters of liquid effluent containing radionuclides stored in large underground tanks at Hanford, Washington $[1,2]$. In all, sixty seven tanks are suspected leakers and there are a great many other contaminant plumes around the sited arising from various sources; surface spills, pumping problems, early waste disposal practices, etc.[1] Near the highest temperature tanks (up to $270^{\circ} \mathrm{C}$, with many tanks having been above $100^{\circ} \mathrm{C}$ for prolonged periods, [7] ) the strongly basic concentrated, aluminum, phosphate and sodium-rich waste solutions[3-6] in contact with silica-rich soil minerals provide an ideal recipe for the in-situ formation of zeolites. Additionally, as cooled fluids flow away from the tanks their $\mathrm{pH}$ will fall as they encounter $\mathrm{CO}_{2}$. This will initiate precipitation of hydrous $\mathrm{Al}$ - hydroxides. The predicted location for these reactions are shown in figure 1 (adapted from Appendix $\mathrm{H}$ of the GW/VZ Integration Project Specification DOE, 1998). [8] 


\section{DISCLAIMER}

This report was prepared as an account of work sponsored by an agency of the United States Government. Neither the United States Government nor any agency thereof, nor any of their employees, make any warranty, express or implied, or assumes any legal liability or responsibility for the accuracy, completeness, or usefulness of any information, apparatus, product, or process disclosed, or represents that its use would not infringe privately owned rights. Reference herein to any specific commercial product, process, or service by trade name, trademark, manufacturer, or otherwise does not necessarily constitute or imply its endorsement, recommendation, or favoring by the United States Government or any agency thereof. The views and opinions of authors expressed herein do not necessarily state or reflect those of the United States Government or any agency thereof. 


\section{DISCLAIMER}

Portions of this document may be illegible in electronic image products. Images are produced from the best available original document. 
Highly soluble radionuclides likely to travel in contaminant plumes include ${ }^{79} \mathrm{Se}$, ${ }^{99} \mathrm{Tc}$ and ${ }^{133} \mathrm{Cs}$. The upper limits of the radionuclides in the solutions are approximately $5.7 \mathrm{ppm}{ }^{133} \mathrm{Cs}, 20 \mathrm{ppm}{ }^{99} \mathrm{Tc}$, and up to $70 \mathrm{ppm}{ }^{79} \mathrm{Se}$.[9] The phases which form as a result of solution interactions with neutralizing media such as $\mathrm{CO}_{2}$ or silicates must be identified in order to determine the location, speciation and phase association of these contaminants within the Vadose zone. Further, changes in soil permability as a result of alteration and precipitation processes must be assessed with regard to their impact on the flow paths of past or future leaks. These questions were addressed by initiating a suite of scoping studies intended to simulate the various changes that would occur as a leaked fluid would (DSSF-7) migrated thorugh the vadose zone toward the water table.

\section{EXPERIMENT}

\section{Soil-Solution Reactions}

Soils used in this study were obtained from the Hanford Reservation and are typical of the sandy surface cover deposited by the last great Lake Missoula flood. The fluid used in these experiments ("DSSF-7 ") was developed to be similar to that originating from rinsing operations associated with tank $101 \mathrm{AW}$ [3]. The major components of the DSSF-7 simulant solution, the radionuclide analogues, and the concentrations of these species are compiled in Table I. The nonradioactive analogues include $\mathrm{Re}$ for ${ }^{99} \mathrm{Tc}$, and nonradioactive $\mathrm{Cs}$ and $\mathrm{Se}$ for ${ }^{13.3} \mathrm{Cs}$ and ${ }^{79} \mathrm{Se}$, respectively. The soils were exposed to DSSF-7 solutions for $1-2$ weeks at $90^{\circ}$ and $200^{\circ} \mathrm{C}$ in Parr reaction vessels and for 82 days at room temperature, $60^{\circ}$, and $90^{\circ} \mathrm{C}$ in polyethylene bottles. After completing the $90^{\circ}$ and $200^{\circ} \mathrm{C}$ experiments the liquid phase was isolated from the solid phase by filtration. Concentrations of $\mathrm{Cs}, \mathrm{Se}$ and $\mathrm{Re}$ in both the solid phases and liquid phases were determined by ICP-Mass Spectrometry. The 82 day experimental fluids did not contain radionuclide surrogates but were used to identify solid alteration products and observe textural features reaulting from the treatment (i.e. grain cementation and zeolite morphologies).

\section{$\mathrm{CO}_{2}=$ Solution Reactions}

Two experiments were also performed to study uptake of $\mathrm{CO}_{2}$ by the DSSF-7 test solution. First, an aliquot of DSSF-7 solution was left stirring at room temperature in contact with the air to verify that eventually even this dilute source of $\mathrm{CO}_{2}$ could neutralize enough hydroxide to initiate precipitation of a solid phase. Second, an accelerated experiment was executed by bubbling pure $\mathrm{CO}_{2}$ gas through DSSF-7 solution at room temperature. There was enough of this second precipitate that it could be isolated by filtration and analyzed by X-ray diffraction (phase identification) and ICP-MS (radionuclide surrogate content). The remaining DSSF-7 solution was also analyzed by ICP-Mass Spectrometry for Se, Cs and Re. 
Table I. Composition of DSSF-7 Simulant Solution

\begin{tabular}{|c|c|c|c|}
\hline Component & $\begin{array}{c}\text { Concentration } \\
\text { in solution }\end{array}$ & Component & $\begin{array}{l}\text { Concentration } \\
\text { in solution }\end{array}$ \\
\hline${ }^{*} \mathrm{Cs}$ & $100 \mathrm{ppm}$ & $\mathrm{Na}_{2} \mathrm{HPO}_{3} \cdot 7 \mathrm{H}_{2} \mathrm{O}$ & $0.014 \mathrm{~mol} / \mathrm{L}$ \\
\hline${ }^{*} \mathrm{Se}$ & $100 \mathrm{ppm}$ & $\mathrm{NaOH}$ & $3.885 \mathrm{~mol} / \mathrm{L}$ \\
\hline${ }^{*} \operatorname{Re}$ & $100 \mathrm{ppm}$ & $\mathrm{Al}\left(\mathrm{NO}_{3}\right)_{3} \cdot 9 \mathrm{H}_{2} \mathrm{O}$ & $0.721 \mathrm{~mol} / \mathrm{L}$ \\
\hline $\mathrm{NaNO}_{3}$ & $1.162 \mathrm{~mol} / \mathrm{L}$ & $\mathrm{Na}_{2} \mathrm{CO}_{3}$ & $0.147 \mathrm{~mol} / \mathrm{L}$ \\
\hline $\mathrm{KNO}_{3}{ }^{3}$ & $0.196 \mathrm{~mol} / \mathrm{L}$ & $\mathrm{NaCl}$ & $0.102 \mathrm{~mol} / \mathrm{L}$ \\
\hline $\mathrm{KOH}$ & $0.749 \mathrm{~mol} / \mathrm{L}$ & $\mathrm{NaNO}_{2}$ & $1.512 \mathrm{~mol} / \mathrm{L}$ \\
\hline $\mathrm{Na}_{2} \mathrm{SO}_{4}$ & $0.008 \mathrm{~mol} / \mathrm{L}$ & & \\
\hline
\end{tabular}

* Radionuclide analogue

\section{RESULTS}

\section{$\underline{\text { Solution-Soil Reactions }}$}

Figure 2 shows the X-ray diffraction spectra of unaltered sandy Hanford soil (a), and Hanford soils exposed to DSSF-7 solution for 82 days at $25^{\circ} \mathrm{C}$ (b), $60^{\circ} \mathrm{C}$ (c) and 90 ${ }^{\circ} \mathrm{C}$ (d). The major phases of the unaltered soils are quartz, plagioclase feldspar and grains of basalt - consisting mainly of feldspar and minor amounts of pyroxene. X-ray diffraction analyses of the soil minerals show that with increasing temperature more of the sample is altered to a cancrinite-group zeolite. At $90^{\circ} \mathrm{C}$ both quartz and feldspar were completely removed from the sample. Basaltic fragments, however, were relatively less effected by the treatment. The unaltered soil (consisting of quartz feldspar and basalt grains[10]) and soil altered by DSSF-7 solution at $90^{\circ} \mathrm{C}$ are compared by SEM in figure 3 . The unaltered soil consists of large, angular grains varying in diameter from several microns to several hundred microns. The altered soil still shows outlines of the original grains, but multiple grains are cemented together by cancrinite overgrowths. The cancrinite overgrowth consists of botryoidal masses (several microns in diameter). Soil alteration as a function of the solution: soil ratio was also studied. At $200^{\circ} \mathrm{C}, 1$ gram of soil and 10 grams of DSSF-7 solution resulted in complete alteration to cancrinite. On the other hand, 8 grams of soil and 10 grams of solution at $200^{\circ} \mathrm{C}$ resulted in incomplete alteration of the minerals and quartz was still the dominant phase observed in the X-ray diffraction. In addition, a different well-formed zeolite was were observed in this sample (figure 4). This phase was tentatively identified as analcime by the crystal morphology and by several minor peaks observed in the X-ray powder diffraction pattern, .

\section{$\underline{\text { Solution- } \mathrm{CO}_{2}} \underline{\text { Reactions }}$}

The precipitate formed from bubbling $\mathrm{CO}_{2}$ through DSSF-7 solution was identified as bayerite, $\mathrm{Al}(\mathrm{OH})_{3}$, by X-ray diffraction. A white precipitate, presumably bayerite, was also noted in the experiment exposing DSSF-7 to air. This suggests the $\mathrm{CO}_{2}$ in the atmosphere is present in sufficient quantity for $\mathrm{Al}(\mathrm{OH})_{3}$ precipitation from a leaked tank fluid. 

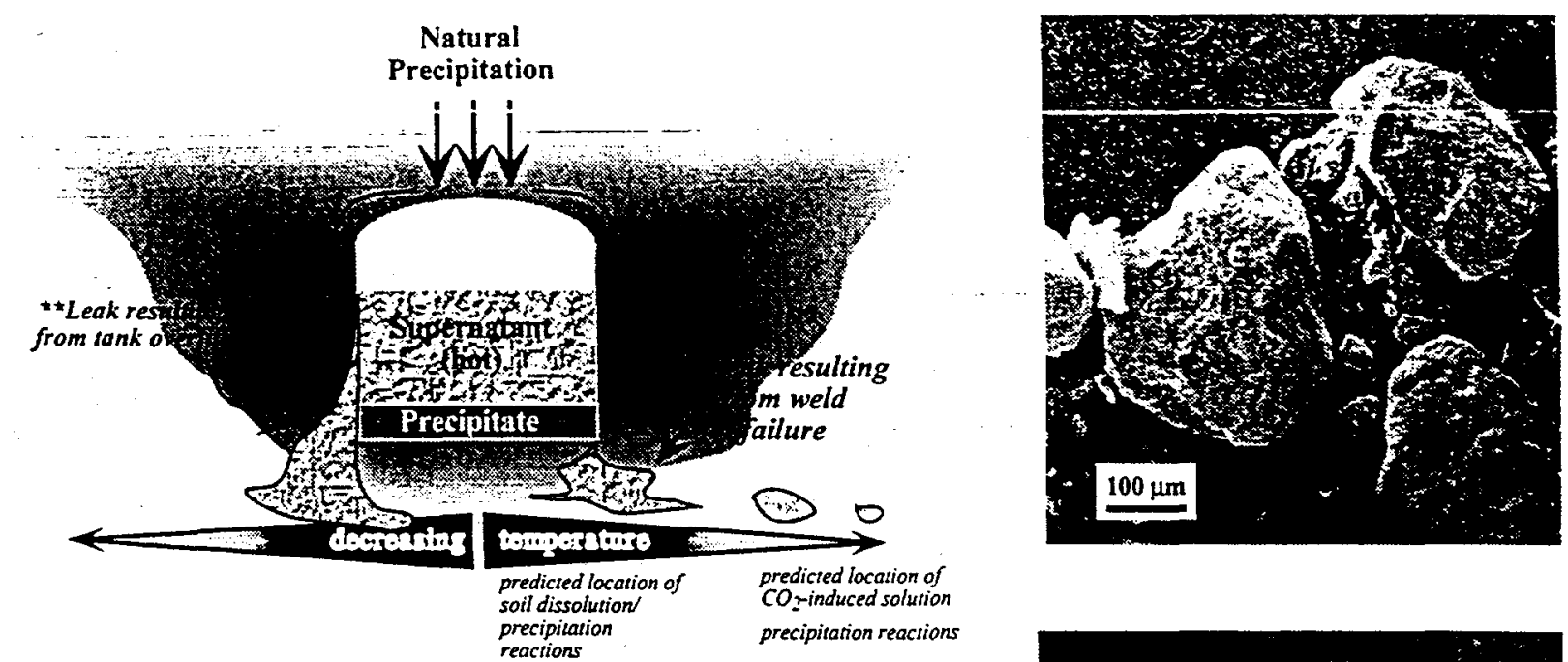

Figure 1. Schematic of a Hanford waste tank, depicting the site of the soil/solution reactions within the Vadose zone.
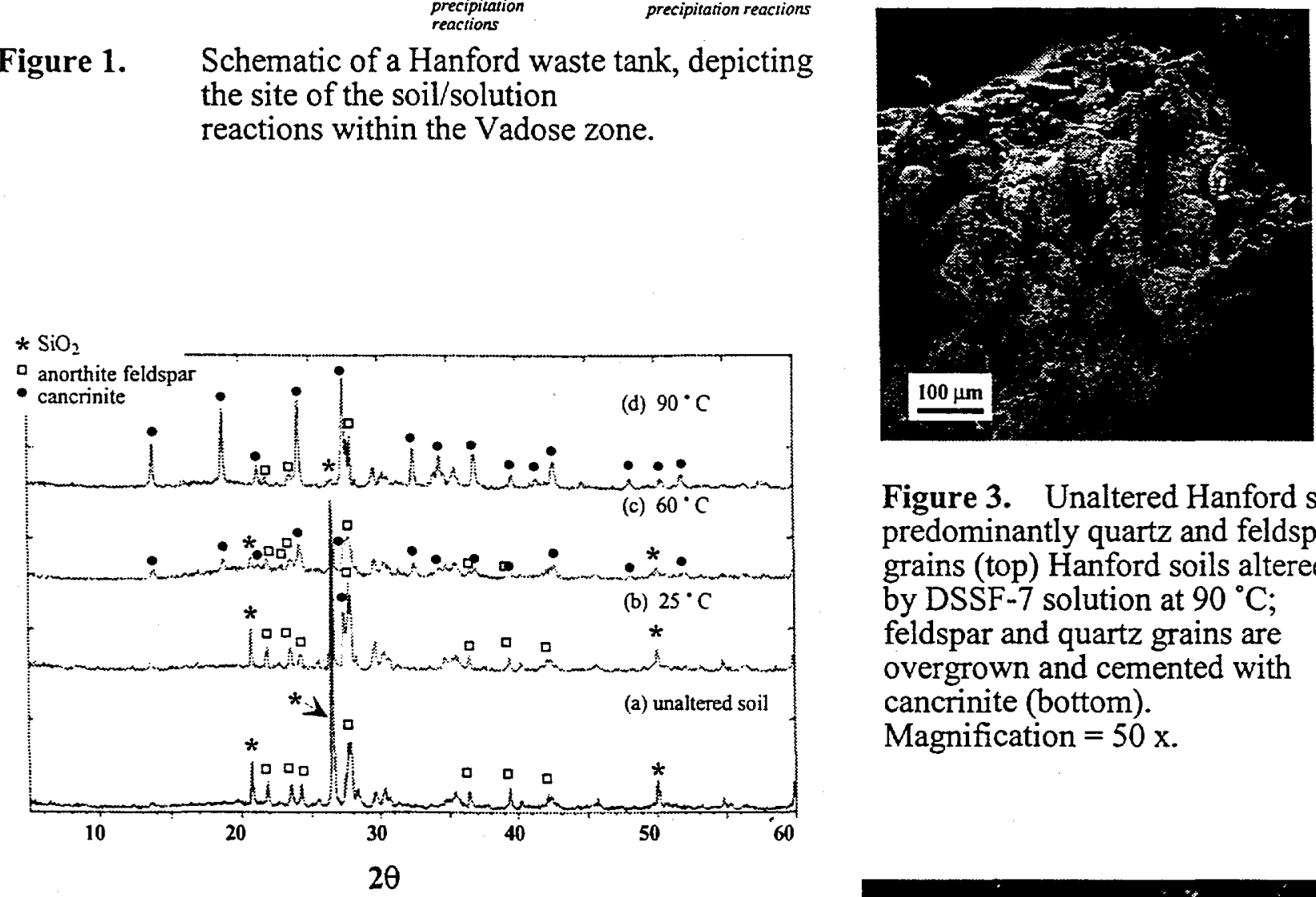

Figure 3. Unaltered Hanford soils; predominantly quartz and feldspar grains (top) Hanford soils altered by $D S S F-7$ solution at $90^{\circ} \mathrm{C}$; feldspar and quartz grains are overgrown and cemented with cancrinite (bottom). Magnification $=50 \mathrm{x}$.

Figure 2. X-ray diffraction spectra of unaltered Hanford soil (a), and soil soaked in DSSF-7 solution for 2 weeks at $25^{\circ} \mathrm{C}(\mathrm{b}), 60^{\circ} \mathrm{C}(\mathrm{c})$ and $90^{\circ} \mathrm{C}(\mathrm{d})$.

Figure 4. Analcime grown on Hanford soils from DSSF-7 solution at $200^{\circ} \mathrm{C}$

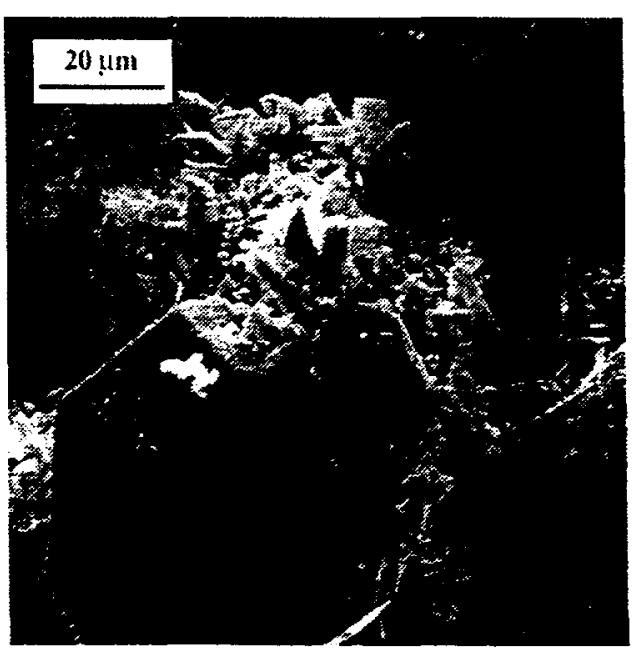




\section{Radionuclide Analogue Sequestration}

$\mathrm{Se}, \mathrm{Cs}$, and Re concentrations were monitored in experiments of DSSF-7 with both Hanford soils and $\mathrm{CO}_{2}$ to determine the radionuclide sequestration ability of the reaction products (results compiled in Table II). Major alteration phases identified by Xray diffraction are cancrinite and analcime (both aluminosilicate zeolites) for the soilsolution experiments, and $\mathrm{Al}(\mathrm{OH})_{3}$ for the $\mathrm{CO}_{2}$ precipitation experiments. The zeolites are capable of sequestering $\mathrm{Cs}^{+}$in micropores, and $\mathrm{Al}(\mathrm{OH})_{3}$ may sandwich $\mathrm{Cs}^{+}$between octahedral layers. The $\mathrm{Se}$ and $\mathrm{Re}$, which exist in solution primarily as $\mathrm{SeO}_{4}{ }^{2-}$ and $\mathrm{ReO}_{4}{ }^{-}$, may coprecipitate or surface adsorb onto alteration phases.[11-14]

In general, a $10-20 \%$ decrease in concentration of the radionuclide analogues was observed in the reaction supernates. Higher soil : solution ratios resulted in removal of more of the radionuclide analogue from solution. There is a noticeable decrease in Cs concentration from the solution of experiment 5 , as well as the relatively high concentration of Cs in the reacted solids (Table II, values in parenthesis). This is the only experiment in which analcime was identified as an alteration product. This suggests that the selectivity for $\mathrm{Cs}$ is greater for analcime than for cancrinite.

Further, both Re and Se were removed from the fluid during the sediment DSSF-7 interaction studies, but were not detectable in the reacted sediments. This suggests that the process responsible for their removal could be reversed by exposing contaminated sediments to fresh groundwater once a plume had passes. It also follows that neither anion seems to have followed the more abundant nitrate, nitrite, and carbonate into the anion sites present in the cancrinite structure. Part of the $\mathrm{Cs}$, however, was retained after the sample was washed which suggests it is fixed in the zeolitic alteration products. Finally, the ability of the bayerite to retain all three radionuclide is notable. Thus, such precipitates may significantly impact radionuclide mobility in the cooler, more distant, parts of the vadose zone.

Table II. Radionuclide Analogue Concentration in Experiment Supernates

Experiment Description

\section{PPM of radionuclide analogue in experiment supernate and in the solid reaction products ( )}

\begin{tabular}{lccc} 
& Se (ppm) & Cs (ppm) & $\operatorname{Re}(\mathbf{p p m})$ \\
\hline 1) $\mathrm{DSSF}$ solution initial concentration & 86 & 96 & 98 \\
2) $1: 10$ soil : solution $90^{\circ} \mathrm{C} / 2$ weeks & $76(>250)$ & $74(49)$ & $89(>5)$ \\
3) $1: 1$ soil : solution $\quad 90^{\circ} \mathrm{C} / 2$ weeks & $72(>250)$ & $63(38)$ & $81(>5)$ \\
4) $1: 10$ soil : solution $200{ }^{\circ} \mathrm{C} / 1$ week & $79(>250)$ & $87(30)$ & $88(>5)$ \\
5) $1: 1$ soil : solution $\quad 200^{\circ} \mathrm{C} / 1$ week & $71(>250)$ & $39(124)$ & $84(>5)$ \\
6) $\mathrm{CO}_{2}$ enhanced $\mathrm{Al}(\mathrm{OH})_{3}$ precipitation & $68(8,390)$ & $78(9,000)$ & $84(8,020)$ \\
\hline
\end{tabular}




\section{CONCLUSIONS}

Studies have been carried out in order to: 1) model the reactions which take place between a hot alkaline tank solution and soil fill adjacent to a leaking tank at Hanford, and 2) predict the fate of ${ }^{133} \mathrm{Cs},{ }^{99} \mathrm{Tc}$, and ${ }^{79}$ Se radionuclides. Preliminary results reveal that at high temperatures the sediments will be zeolitized and at lower temperatrues precipitation of bayerite (or related hydrous Al oxides) may dominate. These studies have also shown that, at least in a batch reactor mode, the radionuclides are only partially immobilized by these changes. Better simulations involving more appropriate mass:fluid ratios and a realistic assessment of mass transport processes are necessary before these results could be applied to quantitatively predicting radionculide distributions in an actual field setting.

Secondly, the overgrowth textures, cementation of grains, and volumenous precipitation of hydrous Al-hydroxide gels all suggest that chemical reactions within a migrating plume will almost certainly alter fluid flow paths adjacent to a leaking tank. This result must be considered when developing vadose zone hydrologic models to predict the transport of radionuclides away from a leaking tank.

\section{ACKNOWLEDGEMENTS:}

This work was supported by the U.S. DOE under contract DE-AC04-94AL85000.

\section{REFERENCES:}

[1] E. K. Wilson, Chemical and Engineering News Sept. 29, 1997 (1997) 30.

[2] D. L. Illman, Chemical and Engineering News June 21, 1993 (1993).

[3] S. F. Agnew, J. G. Watkin, TWRS Characterization Program, report \# LA-UR3590, Los Alamos National Laboratory, Los Alamos 1994.

[4] S. F. Agnew, report \# LA-UR-3860, Pacific Northwest National Lab, Richland, WA 1996.

[5] R. J. Serne, M. I. Wood, report \# PNNL-7279, DE90013546, Pacific Northwest National Labs, Richland, WA 1990.

[6] R. L. Weiss, report \#WHC-SD-WM-ER-309, Pacific Northwest National Lab, Richland, WA 1988.

[7] B. D. Flanagan, report \#WHC-SD-WM-TI-591, Pacific Northwest National Lab, Richland 1994.

[8] National Research Council, DOE, Committee on Subsurface Contamination at DOE Complex Sites: Research Needs and Opportunities 1998.

[9] E. M. J. Kupfer, report \# HNF-SD-WM-TI-740, Pacific Northwest National Lab, Richland, WA 1997.

[10] R. J. Serne, J. M. Zachara, D. S. Burke, report \# PNNL-11495 UC-510, Pacific Northwest National Laboratory, Richland 1998.

[11] L. B. Sand, F. A. Mumpton, Natural Zeolites; Occurrence, Properties, Uses, Pergamon Press, London 1978.

[12] A. J. Ellis, W. A. J. Mahon, Chemistry and Geothermal Systems, Academic Press 1977.

[13] R. M. Barrer, Hydrothermal Chemistry of Zeolites, Academic Press, London 1982.

[14] J. Breck, Zeolite Molecular Sieves, Wiley and Sons, New York 1974. 